\title{
PENERAPAN SISTEM BANGUNAN APUNG SEBAGAI CARA UNTUK BERDAMAI DENGAN BANJIR DI JAKARTA UTARA
}

\author{
Dennis $^{1)}$, Rudy Surya ${ }^{2)}$ \\ 1)Program Studi S1 Arsitektur, Fakultas Teknik, Universitas Tarumanagara, kucingsuper123@gmail.com \\ ${ }^{2)}$ Program Studi S1 Arsitektur, Fakultas Teknik, Universitas Tarumanagara, rudys@ft.untar.ac.id
}

\begin{abstract}
Abstrak
Pemanasan global sudah menjadi masalah yang dihadapi dunia sejak bertahun-tahun lamanya, dan masih belum terdapat penyelesaiannya. Akibat dari pemanasan global sangat banyak, yang paling utama adalah meningkatnya suhu bumi, kemudian menyebabkan kenaikan permukaan air laut. Hal ini menyebabkan terjadinya banjir, terutama banjir rob, di daerah-daerah yang berada di dekat laut, antara lain adalah Jakarta Utara. Daerah ini sudah terkenal sering mengalami banjir, terutama saat turun hujan, besar maupun kecil, juga saat terjadinya pasang air laut. Permasalahan banjir inilah yang kemudian diangkat menjadi isu bagaimana arsitektur menjawab masalah banjir di daerah pantai sebagai penelitian ini. Dalam upaya menyelesaikan masalah tersebut, ada beberapa metode yang dapat digunakan. Diantaranya adalah metode arsitektur metafora, yang merupakan metode yang digunakan dalam merancang bangunan. Tema yang digunakan pada proyek ini adalah beyond ecology. Beyond ecology merupakan sebuah teori dalam membangun yang memperhatikan dan menerapkan hubungan dengan lingkungan dan makhluk hidup sekitarnya. Oleh karena itu, solusi alternatif yang didapat, yang kemudian bisa digunakan untuk membantu menghadapi masalah banjir, adalah dengan cara berdamai dengan banjir, dengan menggunakan pendekatan arsitektur. Solusi arsitektur yang ditawarkan adalah merancang sebuah komunitas apung, yang dapat beradaptasi terhadap naik-turunnya permukaan air laut, sehingga bangunan dapat terbebas dari bencana banjir yang disebabkan oleh pemanasan global tersebut.
\end{abstract}

Kata kunci: Berdamai dengan banjir; Beyond Ecology; Komunitas Apung; Pemanasan global

\begin{abstract}
Global warming has been the world's problem for years that hasn't been solved yet. There are tons of effects caused by global warming, but the one that can be felt the most is the rise of earth's temperature, that also causes rising sea level. This causes a lot of problems, particularly tidal flood, that is happening in most areas near the sea, such as, North Jakarta. This area is known to be flooded a lot, especially when rain is pouring, and when the tide is rising. This is the issue that will be brought up in this research, on how architecture can solve the flooding problem on the coastal area. In the spirit of solving the issue, there are some methods that will be implemented. The first one is metaphor architecture; this method will be used in designing the building. The theme used for designing is beyond ecology. Beyond ecology is a designing theory which implements the relationships between the ecosystem and the living things around the site of the building. The aim in this research is to propose an alternate solution that can be used to help in preventing the tidal flood, by making peace with the flood with architectural approach. The proposed architecture solution is to create a floating community, that can adapt with the rising sea level so that everyone can avoid the flooding that is caused by global warming.
\end{abstract}

Keywords: Beyond ecology; Floating community; Global warming; Making peace with the flood 


\section{PENDAHULUAN}

\section{Latar Belakang}

Pemanasan global adalah sebuah bencana yang sudah terjadi sejak lama. Hal ini menyebabkan suhu di bumi terus bertambah setiap harinya. Menurut NASA, sejak tahun 2000, bumi mengalami tahun-tahun terpanasnya dalam 134 tahun terakhir (Turrentine, 2021). Secara garis besar, pemanasan global disebabkan oleh efek rumah kaca. Efek rumah kaca adalah suatu kejadian dimana bumi dan atmosfirnya bertindak bagaikan sebuah rumah kaca. Radiasi matahari yang masuk ke bumi, yang seharusnya dipantulkan kembali ke luar bumi tidak dapat terjadi. Hal ini disebabkan oleh manusia. Lebih tepatnya alat-alat industrial yang diciptakan oleh manusia, yang menggunakan tenaga batu bara, dan mengeluarkan emisi gas karbon dioksida, metana, dan gas rumah kaca lainnya (Bolin \& Doos, 1989).

Banyak hal yang terjadi karena suhu bumi terus meningkat. Salah satunya adalah mencairnya es di kutub utara dan selatan, juga di pegunungan. Hal tersebut kemudian menyebabkan naiknya permukaan air laut. Tidak hanya pemanasan global, masalah yang dihadapi manusia belum berhenti disitu. Pembangunan yang terus dilakukan, terutama di Jakarta, menyebabkan tanah di Jakarta terus turun setiap harinya. Hingga saat ini, sudah ada Sebagian tanah Jakarta yang berada di bawah permukaan air laut. Turunnya tanah, ditambah dengan terus meningkatnya volume air laut karena pemanasan global, merupakan sebuah kombinasi yang sangat buruk untuk Jakarta. Hasil yang terjadi, yang sudah sering kita rasakan selama ini, adalah banjir. Jakarta terus mengalami banjir saat turun hujan deras, maupun saat air laut pasang. Berbagai upaya yang sudah diusahakan oleh pemerintah untuk mengatasi ini, namun semuanya masih belum berhasil. Oleh karena itu, solusi arsitektur yang ditawarkan adalah dengan mencoba untuk berdamai dengan banjir. Dengan merancang sebuah bangunan yang dapat bertahan dan beradaptasi dengan banjir yang ada di Jakarta.

\section{Rumusan Permasalahan}

Dari latar uraian latar belakang dan masalah yang sudah ada, dapat dirumuskan beberapa pertanyaan seperti bagaimana cara arsitektur dapat menyelesaikan masalah banjir di Jakarta? apakah arsitek dapat merancang bangunan dengan berdamai dengan banjir yang disebabkan oleh peamanasan global? apakah komunitas apung bisa menjadi solusi berdamai dengan banjir?

\section{Tujuan}

Dari rumusan masalah yang sudah ada, tujuan yang diharapkan dari proyek ini adalah memberikan solusi arsitektur untuk membantu masyarakat dalam menghadapi bencana banjir, merancang dan mempelajari jenis-jenis konsep bangunan yang dapat digunakan untuk berdamai dengan banjir, merancang sebuah komunitas apung sebagai bentuk adaptasi dan penyesuaian diri terhadap lingkungan yang terus berubah karena pemanasan global.

\section{KAJIAN LITERATUR \\ Beyond Ecology}

Ekologi adalah salah satu cabang biologi yang mempelajari tentang hubungan antara makhluk hidup dengan lingkungan hidupnya. Ilmu ini bertujuan untuk memahami hubungan yang krusial antara tumbuhan, hewan, dan dunia sekitarnya. Ekologi juga mempelajari tentang keuntungan dari berbagai ekosistem, dan bagaimana kita bisa memaksimalkan sumber daya alam, namun tetap menjaga alam tanpa merusaknya untuk masa depan kita. Pembangunan yang dilakukan tidaklah hanya untuk kepentingan manusia, namun juga untuk kebaikan makhluk hidup lain dan alam tempat bangunan tersebut berada. Oleh karena itu, untuk menghindari ekologi yang antropo-sentris, perlu adanya acuan dan parameter yang harus diikuti (Kuliah tamu Pak Agustinus Sutanto, 2021). Parameter tersebut adalah: 


\section{Kontekstual}

Menurut Anthony C Antoniades (Poetics of Architecture), kontekstual merupakan klasifikasi dari bidang konteks dalam arsitektur yang dapat berhubungan dengan site dari lingkungan, kondisi bangunan sekitar, masyarakat, budaya, dan material didaerah setempat. Tujuanya untuk mengarahkan desain ke dalam suatu perancangan desain. Jadi, arsitektur kontekstual adalah suatu metode perancangan yang mengkaitkan bangunan baru dengan menyelaraskan nilai-nilai karakteristik terhadap lingkungan sekitar (Marlina, 2019).

\section{Energy and Emission}

Energi dan emisi merupakan hasil pembuangan dari pembakaran, biasanya hasil dari pembakaran batu bara, yang menghasilkan gas CO2. Secara umum, emisi berarti gas pembuangan hasil dari pembakaran bahan bakar. Energi dan emisi ini biasanya berasal dari transportasi, penggunaan listrik, dan masih banyak lagi. Untuk menciptakan bangunan yang melampaui ekologi, maka energi dan emisi dari bangunan tersebut harus diperhatikan, bahkan dihilangkan sama sekali.

\section{Adaptation}

Beradaptasi berarti menyesuaikan diri sesuai dengan lingkungan. Dalam hal ini, arsitektur yang beradaptasi berarti arsitektur yang mampu disesuaikan dengan tapaknya. Jika tapak berada di lokasi yang sering hujan dan badai, maka bangunan juga harus bisa bertahan dari curahan hujan dan badai dengan intensitas yang besar, tanpa mengalami kerusakan.

\section{New Technology}

Penggunaan teknologi yang terbaru, yang diintegrasikan ke dalam bangunan, menjadi salah satu poin penting dalam membangun arsitektur ekologis. Dengan teknologi yang paling baru, emisi dari penggunaan listrik dan bahan bakar bisa berkurang dengan signifikan. Penggunaan panel surya, atau turbin untuk menghasilkan listrik bisa menjadi alternatif yang untuk mendapatkan sumber listrik yang ramah lingkungan. Selain itu, arsitektur juga diharapkan dapat berkembang bersema perkembangan IPTEK. Teknologi dalam arsitektur, tidak hanya diintegrasikan pada bangunan, namun juga pada saat proses pembangunan, juga pada bahan bangunan yang digunakan (Sebestyén \& Pollington, 2003).

\section{Digital Sustainability}

Digital sustainability dalam arsitektur adalah sebuah gerakan sadar akan lingkungan, yang berusaha untuk mengintegrasikan teknologi terkini, dengan konsep green architecture. Hal ini berarti kita harus bisa mencari cara untuk mengimplementasikan teknologi digital dalam konsep arsitektural yang berkelanjutan. Dengan penerapan ini, maka kita akan lebih memikirkan untuk menggabungkan teknologi dengan desain, agar bisa mencapai keterhubungan antara arsitektur berkelanjutan dengan teknologi.

\section{Resilience}

Resilience adalah suatu bentuk ketahanan, kemampuan untuk tetap bertahan dan kembali bangkit setelah terjatuh. Dalam hal ini, arsitektur harus bisa bertahan terhadap kondisi apapun yang mungkin akan datang. Dalam konteks ini, arsitektur harus bisa bertahan terhadap ancaman ekologi yang ada. Ancaman ekologi biasanya berupa bencana alam, seperti badai, tsunami, gempa bumi, dan lainnya (Hewitt, Oberg, Coronado, \& Andrews, 2019).

\section{Perubahan iklim}

Iklim adalah sebuah istilah yang digunakan untuk menjelaskan keadaan cuaca pada suatu tempat. Perubahan iklim adalah sebuah perubahan yang signifikan terhadap kondisi cuaca, misalnya cuaca di Indonesia berubah menjadi lebih kering, lembab, panas, atau dingin, dalam 
kurun waktu tertentu. Istilah perubahan iklim dan pemanasan global sering kali kita dengar, dan banyak juga yang salah mengartikannya. Faktanya, pemanasan global hanyalah salah satu dampak dari perubahan iklim (Denchak, 2017).

\section{Pemanasan Global}

Pemanasan global adalah sebuah fenomena dimana suhu rata-rata bumi terus meningkat. Hal ini menyebabkan perubahan cuaca yang mempengaruhi ekosistem bumi. Perubahan iklim disebabkan oleh semakin parahnya efek rumah kaca. Sudah diprediksi jika pemanasan global terus terjadi, maka suhu rata-rata bumi akan meningkat sekitar 1.5 hingga $5.3^{\circ} \mathrm{C}$ pada tahun 2100. Hal ini akan menjadi sangat mematikan bagi manusia, maupun makhluk hidup dan lingkungan yang ada di bumi (Picard, 2021).

\section{Dampak Pemanasan Global}

Dampak pemanasan global dapat dilihat dalam beberapa aspek, yaitu dampak terhadap cuaca, dan dampak terhadap lautan. Selama bertahun-tahun, ahli cuaca di seluruh dunia sudah memperhatikan dampak dari pemanasan global terhadap iklim di berbagai negara. Dampaknya sangatlah besar, seperti kekeringan, banjir, badai, kebakaran, musim dingin tanpa salju, dan lainnya. Sedangkan dampaknya terhadap lautan juga tidak kalah besarnya. Permafrost atau tanah beku, dan es di kutub mencair dengan laju yang sangat cepat. Dalam 1 abad terakhir, permukaan laut sudah meningkat setinggi $18 \mathrm{~cm}$ (sudah termasuk peningkatan setinggi $6 \mathrm{~cm}$ dalam 20 tahun terakhir). Diprediksi pada tahun 2100, permukaan air laut akan meningkat setinggi 1 meter (Picard, 2021).

\section{Banjir Rob}

Seiring dengan terus meningkatnya permukaan air laut, terjadilah dampak selanjutnya, yaitu banjir rob. Banjir rob awalnya dianggap masalah sepele yang hanya muncul pada saat air laut pasang saja. Namun, lama-kelamaan, kehadiran banjir rob menjadi semakin sering, dan kerusakan yang ditimbulkan pun menjadi semakin parah. Banjir rob bisa datang pada saat air laut pasang, juga pada saat turun hujan yang cukup lebat. Kedatangannya yang tidak terduga lah yang menyebabkan masalah bagi masyarakat yang tinggal di daerah pesisir (Morra, 2015).

\section{Bangunan Apung}

Bangunan apung merupakan sebuah unit bangunan yang dilengkapi dengan sistem apung, seperti kapal, yang memungkinkan bangunan tersebut untuk mengapung di atas air. Pada umumnya, bangunan apung ini dijangkar secara permanen, maupun sementara, dan tidak dilengkapi dengan mesin, sehingga memerlukan bantuan derekan kapal untuk menggerakkannya. Ada beberapa cara yang dapat digunakan untuk mendesain bangunan apung, yaitu cekungan struktural yang dibuat dari beton, tongkang, atau polystyrene yang dapat mengapung di atas air. Semua struktur tersebut memiliki kelebihan dan kekurangannya masingmasing, tergantung dari kondisi air yang diapunginya.

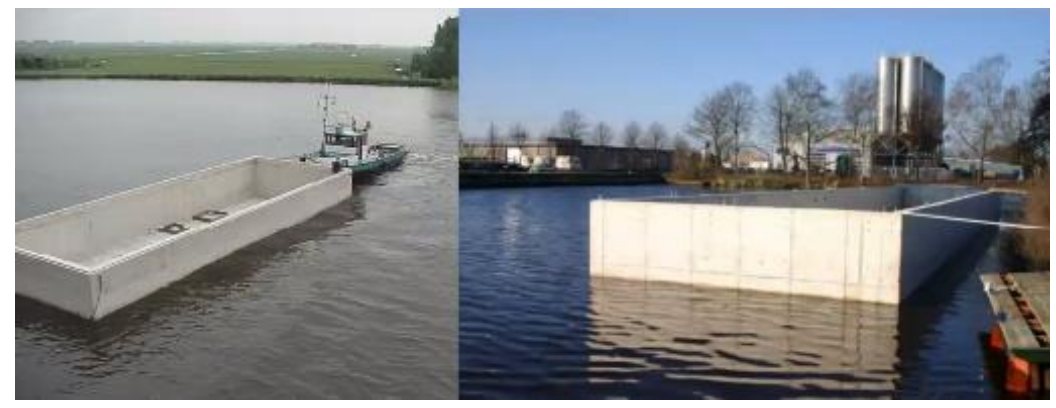

Gambar 1. Struktur Cekungan dari Beton

Sumber: Daliana Suryawinata, Seminar kampung apung oleh IMARTA, 2021 
Teknologi yang sering digunakan untuk bangunan apung adalah dengan menggunakan beton yang berbentuk cekungan. Salah satu keuntungan dari struktur ini adalah karena bebannya yang lebih berat dan keseimbangannya tinggi, sehingga struktur ini menjadi lebih stabil. Hal ini sangatlah penting mengingat gerakan perairan yang tidak menentu. Bangunan apung juga disarankan untuk menggunakan material yang lebih ringan, seperti kayu dan bambu, karena kemampuan apung dari beton terbatas, sehingga saat ditinggali manusia, bangunan tidak tenggelam. Penting juga untuk memperhatikan beban di dalam bangunan. Jangan sampai bangunan berat pada satu sisi, karena dapat menyebabkan bangunan menjadi miring dan memperkuat resiko bangunan terbalik dan tenggelam. Oleh karena itu, jika pada satu sisi bangunan diberi perabot yang berat, maka di sisi lainnya harus dikompensasi dengan menggunakan perabot yang berat juga, atau dengan bantuan struktur pemberat.

\section{Floating Community}

Floating Community adalah sebuah komunitas di Belanda. Komunitas ini adalah komunitas warga yang beralih dan tinggal di rumah apung. Hal ini merupakan sebuah bentuk adaptasi yang dilakukan oleh masyarakatnya terhadap bencana banjir yang sudah menggenangi Belanda sejak dulu. Konsep pemikiran yang perlu diikuti dari floating community adalah untuk berusaha beradaptasi dan berdamai dengan alam, bukan melawan atau mencegahnya. Perubahan iklim sudah berlangsung, banyak yang bisa kita lakukan untuk mencegahnya, namun hingga sekarang, kita masih belum menemukan jawaban pasti untuk melawan perubahan iklim. Oleh karena itu, yang saat ini bisa kita lakukan adalah untuk mencoba improvisasi dan beradaptasi dengan kondisi yang sedang kita alami saat ini.

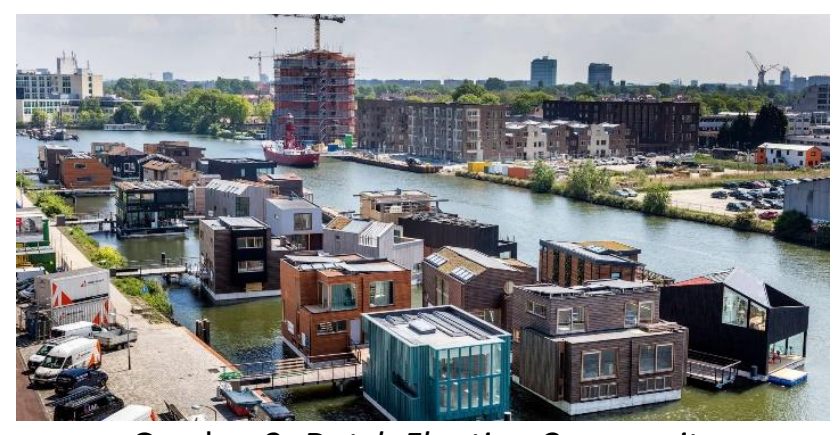

Gambar 2. Dutch Floating Community

Sumber: https://www.metabolic.nl/news/dutch-floating-neighborhood-rises-to-the-challenge-ofclimate-change/

Bangunan apung bukanlah hal yang baru. Bangunan apung tradisional sudah banyak bisa ditemukan, bahkan di Indonesia sendiri. Yang menjadi hal baru adalah untuk mengintegrasikan konsep kehidupan di atas air dengan teknologi yang lebih modern. Floating community yang ada di Belanda merupakan sebuah evolusi dari houseboat atau rumah kapal. Houseboat adalah sebuah perahu yang di desain atau dimodifikasi menjadi sebuah rumah atau tempat tinggal. Rumah kapal ini ada yang dilengkapi dengan mesin, agar bisa dengan mudah dipindahkan kemanapun saat diperlukan. Meskipun begitu, rumah kapal tetap dijangkar agar tidak bergerak ke sana dan ke mari. Rumah apung inilah yang kemudian diusulkan sebagai solusi arsitektur untuk mendesain bangunan yang berdamai dengan banjir. Dengan mendesain bangunan yang bisa mengapung, tinggi rendahnya air laut dan turunnya tanah tidak akan mempengaruhi kondisi bangunan. Sehingga bangunan ini bisa menjadi pilihan yang tepat dan menjadi bangunan pelopor yang dapat berdamai dengan banjir di Jakarta, terutama banjir rob. 


\section{METODE}

Metode penelitian yang digunakan adalah kualitatif. Pengumpulan data, melalui studi literatur yang sudah ada.

\section{Beyond Ecology}

Seperti sudah dijelaskan pada bab sebelumnya, beyond ecology perlu diterapkan, agar dalam merancang bangunan, tidak hanya memperhatikan kepentingan manusia saja, namun juga lingkungan dan makhluk hidup di sekitarnya. Aspek beyond ecology yang kemudian akan diterapkan pada rancangan adalah energy and emission, new technology, dan digital sustainability.

\section{Arsitektur Meminjam}

Meminjam atau Borrowing adalah istilah yang dipakai penulis untuk sebuah tindakan arsitektur yang berkaitan dengan melihat sesuatu (biasanya berkaitan dengan benda yang kasat mata) dipinjam sebagai sebuah referensi ide, lalu diterjemahkan kedalam bentuk arsitektural. Dalam proses perterjemahan bentuk inilah, yang akan membangun imaginasi persepsi dari bentuk asli yang dipinjam. Menurut buku Peta Metode Desain dari Agustinus Sutanto, ada 3 istilah yang berdekatan dengan arsitektur meminjam, yaitu Metaphor, Mimicry, dan Mimesis. Inti dari metafora adalah pemahaman dan mengalami satu hal dalam hal yang lain; salah satu cara mendasar dalam memproyeksikan sebuah struktur, membuat koneksi baru, dan membentuk kembali sebuah pengalaman; membuat fitur-fitur baru dalam suatu objek atau sebuah situasi; meningkatkan persepsi kita tentang realitas dengan menghancurkan perasaan terhadap realitas, dan kenyataan itu melewati fase metamorfosis melalui metafora. Mimikri menurut New World College Dictionary dari Webster adalah "kemiripan yang dekat, dalam warna, bentuk, atau perilaku dari satu organisme dengan organisme lain atau pada beberapa objek di lingkungannya... itu berfungsi untuk menyamarkan atau menyembunyikan organisme dari predator." Efek dari mimikri adalah kamuflase. Madeleine Kelly dalam tulisannya Mimicry and Mimesis: Matrix Insect mengungkapkan bahwa mimesis adalah menghubungkan kehadiran dan ketidakhadiran, karena mereka selalu menggantikan tubuh yang tidak ada. Dalam melipat dan menggandakan, gambar menghidupkan kembali yang hidup serta menghidupkan yang mati, sehingga secara dinamis mereplikasi penampilan. Mimesis, yang diterjemahkan secara kasar, berarti menempatkan presentasi artistik suatu gagasan ke dalam benak orang-orang yang kemudian mengaitkannya dengan pengalaman mereka dan akhirnya merasakan apa yang diinginkan oleh perupa (Sutanto, 2020).

\section{DISKUSI DAN HASIL}

Sebelum masuk ke konsep perancangan, perlu diingat bahwa bangunan akan dibangun di atas air laut. Oleh karena itu, konsep dan bentuk bangunan yang kemudian akan dihasilkan perlu memikirkan tentang kondisi laut. Hal yang perlu diperhatikan adalah sebagai berikut.

\section{Sistem Pengapungan}

Agar bangunan apung bisa mengapung, ada beberapa cara yang dapat digunakan. Cara yang paling sering kita temui adalah dengan menancapkan tiang atau fondasi ke dalam air hingga menuju dasarnya. Hampir sama seperti saat membangun di atas tanah biasa, pondasi ditancapkan ke dalam tanah. 


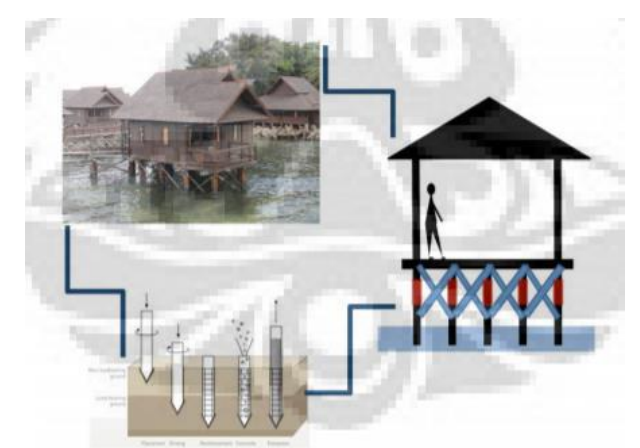

Gambar 3. Bangunan Apung yang Sudah Ada

Sumber: http://lib.ui.ac.id/naskahringkas/2016-03/S46050-Mayang\%20Wulandari\%20Naro\%20Putri

Sistem bangunan apung yang seperti gambar di atas memang sudah sering kita lihat, namun jika dikaitkan dengan isu pemanasan global dan banjir yang sudah dijabarkan pada bab sebelumnya, bangunan seperti ini masih belum bisa menyelesaikan isu tersebut. Hal itu karena bangunan apung yang seperti ini belum mampu beradaptasi dengan naik-turunnya permukaan air laut, sehingga masih berpotensi terkena banjir. Oleh karena itu, sistem pengapungan yang akan digunakan pada bangunan yang dirancang adalah yang tidak menancapkan pondasi ke tanah, melainkan yang benar-benar mengapung di atas air.

Dengan menggunakan struktur yang menyerupai lambung kapal, maka bangunan akan bisa mengapung di atas air secara bebas. Bangunan pun akan bisa beradaptasi dengan naik-turunnya permukaan air laut, sehingga bisa beradaptasi jika air laut sedang pasang, maupun surut. Bangunan seperti inilah yang diharapkan dapat menjadi solusi untuk mengatasi masalah kebanjiran yang ada. Tanpa membangun waduk atau tanggul yang memakan waktu dan biaya yang besar, tanpa merusak laut dan alam.

\section{Sistem Tambat atau Jangkar}

Karena bangunan dirancang dengan struktur yang menyerupai kapal, yang dapat mengapung secara bebas di atas air, maka harus juga dipikirkan sistem tambat atau jangkarnya. Ada beberapa jenis sistem penambatan bangunan apung, yaitu dengan menggunakan jangkar rantai, besi hollow, atau batangan besi, yang kedua adalah dengan menggunakan tension leg platform, yang terakhir adalah rubber fender.

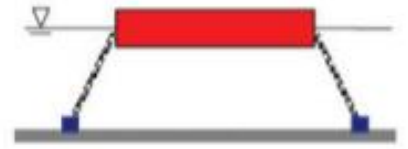

(b) Chain/Cable

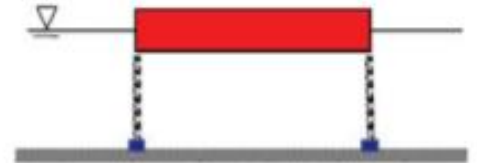

(b) Tension Leg

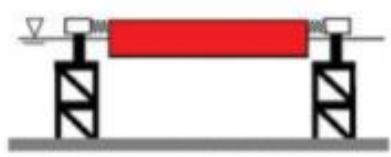

(c) Rubber fender-Dolphin

Gambar 4. Jenis-jenis Sistem Tambat

Sumber: https://www.sciencedirect.com/science/article/pii/S1877705811010848

Sistem tambat yang kemudian diterapkan pada bangunan adalah tambat yang menggunakan batangan besi, yang kemudian ditancapkan ke dasar laut. Di bagian pelampung bangunan kemudian diberi pengait, agar bisa mengaitkan bangunan dengan tambat yang sudah ditancapkan, seperti pada gambar 5 . 


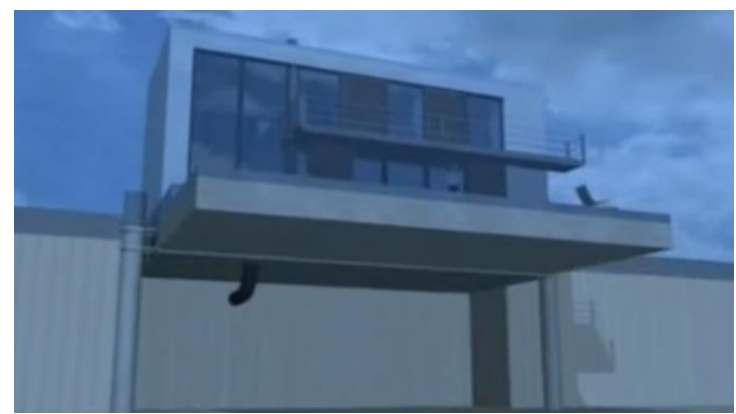

Gambar 5. Pengaitan Tambat dengan Bangunan

Sumber: www.npr.org

Dengan demikian, meskipun permukaan air laut naik, bangunan tetap bisa menyesuaikan dengan ikut naik bersama permukaan air. Penggunaan tambat ini juga dengan pertimbangan agar bangunan lebih stabil dan tidak banyak bergerak bersama arus air, karena bangunan dikaitkan dengan tambat yang ditancap ke bawah air. Inilah yang kemudian dapat diterapkan pada bangunan apung, agar bisa terhindar dari bencana banjir.

\section{Off the Grid}

Istilah off the grid adalah istilah yang digunakan untuk bangunan yang tidak terikat pada sistem utilitas perkotaan, terutama sistem listrik dan air. Oleh karena itu, bangunan yang dirancang kana menerapkan sistem off the grid. Alasan yang dapat digunakan untuk mendukung keputusan ini adalah sulitnya menghubungkan sistem listrik dan air ke bangunan yang berada di atas laut. Oleh karena itu, sistem listrik dan air akan dipenuhi sendiri oleh kawasan. Untuk listrik, akan digunakan panel surya pada bagian atap bangunan. Tidak hanya pada atap bangunan, panel surya juga akan dipasang pada kanopi-kanopi di sepanjang jalur penghubung antar bangunan. Kebutuhan listrik kawasan cukup besar, sehingga membutuhkan panel surya yang cukup banyak juga. Untuk sistem air bersih dan air kotor juga dapat diselesaikan dari dalam kawasan sendiri. Untuk air kotor dapat diproses dan didaur ulang kembali menjadi biogas dan pupuk. Biogas kemudian dapat dimanfaatkan kembali untuk menjadi bahan bakar untuk memasak, kemudian pupuk dapat digunakan untuk tanaman yang ada di tiap bangunan.
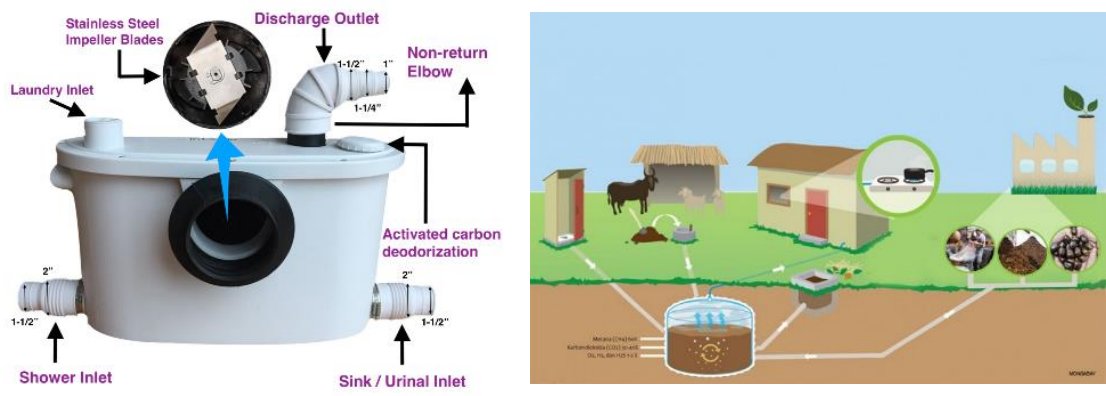

Gambar 6. Proses Daur Ulang Kotoran Manusia

Sumber:

https://www.listrikindonesia.com/menyulap_limbah_kotoran_menjadi_tenaga_listrik_3868.htm

Prosesnya cukup mudah. Pertama, kotoran yang dari kloset kemudian diproses dengan menggunakan macerator pump, yang berfungsi untuk mengubah kotoran-kotoran padat menjadi cair. Setelah kotoran berbentuk cair, kemudian ditampung di tangka penyimpanan. Gas yang dihasilkan dari tangki kemudian dihubungkan dengan kompor untuk memasak. Kemudian sisa kotorannya bisa dimanfaatkan menjadi pupuk. 


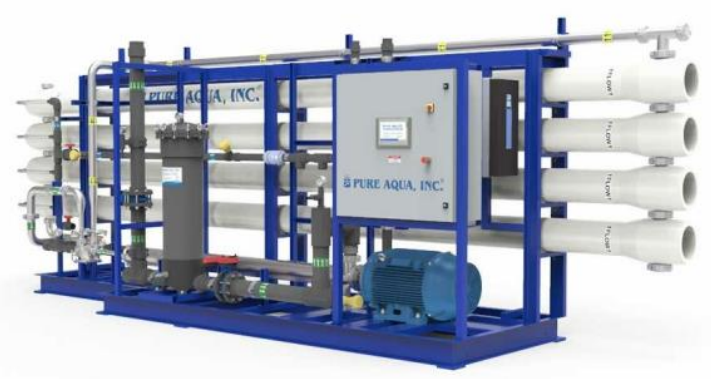

Gambar 7. Sistem Desalinasi Reverse Osmosis

Sumber: https://pureaqua.com/industrial-seawater-reverse-osmosis-desalination-systems/

Kemudian, untuk sistem air bersih, dapat menggunakan sistem desalinasi air laut. Desalinasi air laut dapat menggunakan beberapa cara, yaitu dengan memanaskan air hingga menguap, bisa juga dengan menggunakan sistem reverse osmosis. Sistem reverse osmosis inilah yang akan digunakan, dengan alasan prosesnya lebih cepat, efisien, dan tidak memakan biaya yang besar. Sistem ini tentu saja menggunakan listrik. Kebutuhan listrik dapat dipenuhi melalui panel surya yang tersebar di seluruh kawasan (Greenlee, Lawler, Freeman, Marrot, \& Moulin, 2009).

\section{Program Ruang}

Program yang kemudian didapat secara arsitektur untuk membuat bangunan yang bisa berdamai dengan banjir di Jakarta adalah untuk membuat sebuah komunitas apung. Indonesia merupakan negara bekas jajahan Belanda, oleh sebab itu, tidak ada salahnya jika kita kembali mengikuti jejak Belanda dalam mencoba mengatas banjir di negaranya. Belanda sudah mulai mencoba untuk membuat kota apung, namun, ada baiknya jika kita mencoba memulai dari langkah kecil. Komunitas apung yang diusulkan adalah sebuah perkumpulan yang beralih dari daratan menuju lautan. Fasilitas yang ada pada komunitas ini meliputi fasilitas umum yang ada pada standar desa, yaitu ada rumah pemukiman warga, dan fasilitas umum yang dapat menunjang pemukiman (Banyuurip, banyuurip.desa.id, 2018).

\section{Pemukiman Warga}

Pemukiman warga berupa susunan rumah yang dapat ditinggali oleh warga, baik dari sekitar tapak, maupun dari jauh. Jenis rumah yang ditawarkan ada 2 jenis, yaitu rumah tinggal berkapasitas 4 orang, dan rumah tinggal berkapasitas 2 orang.

\section{Fasilitas Umum}

Fasilitas umum yang diperlukan untuk menunjang kehidupan warga yang paling utama adalah utilitas. Sistem utilitas harus mampu untuk mewadahi kebutuhan utilitas warga, tanpa bantuan utilitas kota, seperti listrik, pembuangan, dan air bersih. Fasilitas umum lainnya yang diperlukan adalah fasilitas pendukung yang berfungsi untuk mewadahi kebutuhan warga.

\section{Desain Bangunan}

Metode perancangan yang digunakan adalah arsitektur metafor. Inspirasi diambil dari gelombang. Gelombang yang ada pada air, biasanya dihasilkan oleh tiupan angin, namun bisa juga dihasilkan dari tetesan air, yang menyebabkan efek riak pada air, yang juga menghasilkan gelombang kecil pada air. 

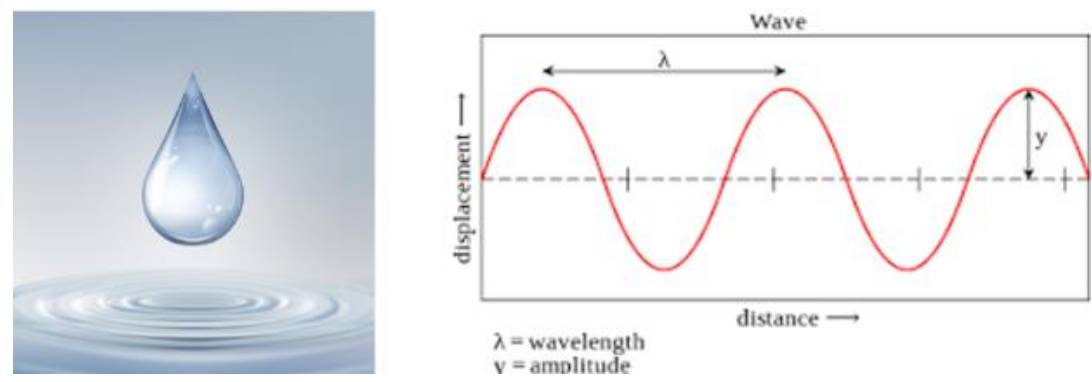

Gambar 8. Tetesan Air dan Gelombang

Sumber: www.google.com

Kedua hal tersebut kemudian disusun kembali dengan menggunakan metode metafor, yaitu meminjam bentuk dari glombang dan efek riak yang tercipta pada air, sehingga menghasilkan bentuk susunan kawasan sebagai berikut.
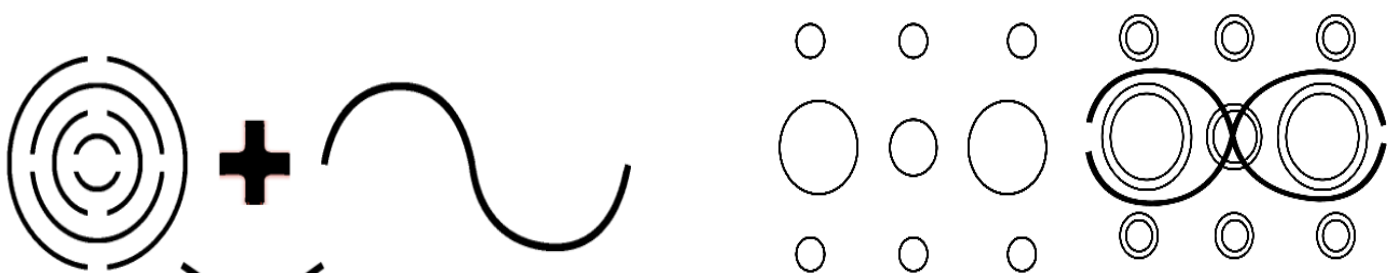

Gambar 9. Pembentukkan Massa Sumber: Pribadi, 2021

Dari konsep tersebut akhirnya menghasilkan sebuah bentuk rancangan bangunan, yang kemudian masih akan diolah kembali agar bisa disesuaikan dengan fungsinya. Bentuk setengah lingkaran pada gambar merupakan gambaran letak dari rumah warga yang akan dirancang, dengan fasilitas umum yang akan disediakan pada tapak diletakan di bagian tengah pada gambar.

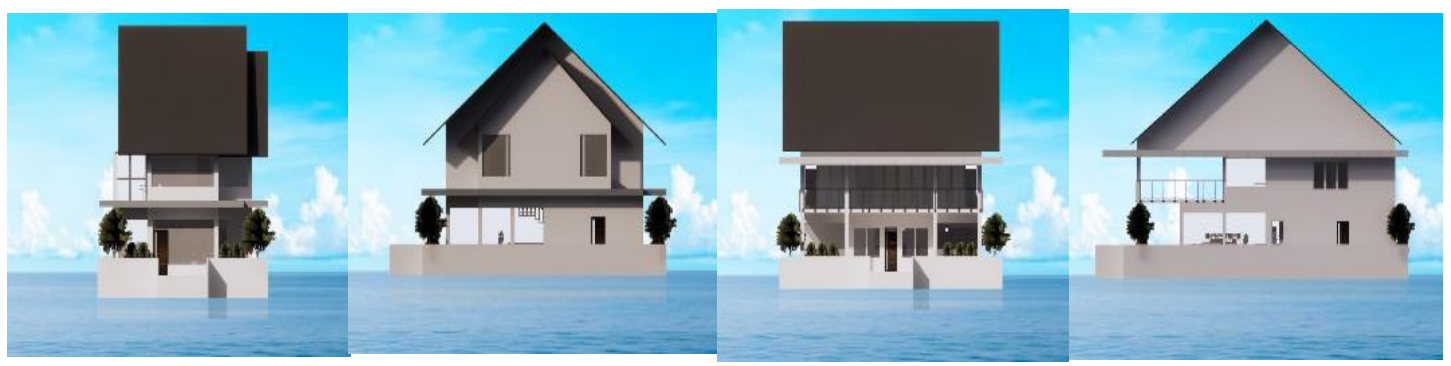

Gambar 10. Tampak Depan dan Samping Rumah Tipe 1 dan 2 Sumber: Penulis, 2021

Desain rumah ada 2 tipe, yang dibedakan dari luasannya. Desain rumah dibuat sederhana, namun tetap masih memperhatikan tapak, yaitu di laut. Oleh karena itu juga tetap memperhatikan dan harus bisa memanfaatkan laut yang ada. Sehingga laut tidak hanya menjadi tapak, tapi juga dapat dinikmati oleh penghuni bangunan. Desain bangunan juga tentunya memperhatikan iklim tropis, dengan menggunakan overhang atap yang cukup panjang, guna melindungi penghuni dari sinar matahari yang terlalu terik, maupun hujan. 


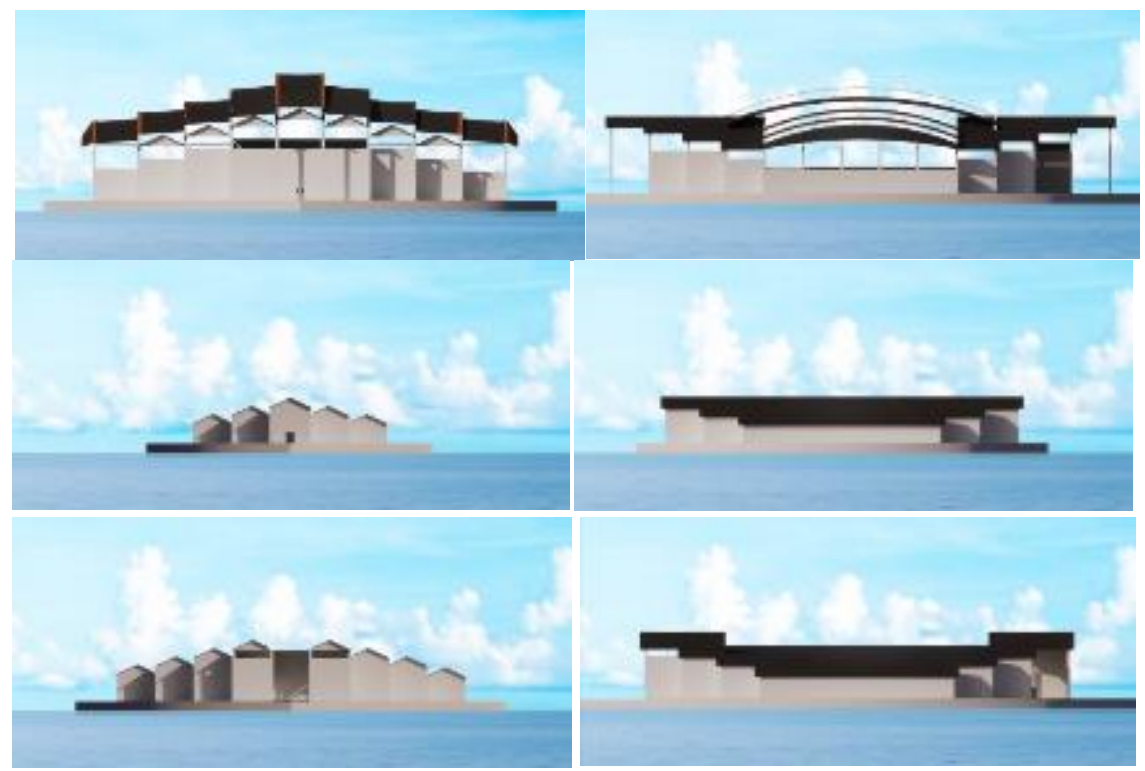

Gambar 11. Tampak Depan dan Samping Fasilitas Umum

Sumber: Penulis, 2021

Fasilitas umum yang disediakan pada tapak adalah sports club, pet club, dan supermarket. Fasilitas tersebut disediakan dengan mempertimbangkan target penghuni dari komunitas apung ini. Target penghuninya adalah orang-orang menengah keatas, sehingga memiliki kegiatan rekreasi yang berbeda dari penghuni kalangan menengah atau kebawah. Sports club dirancang agar penghuni bangunan bisa melakukan berbagai olahraga, seperti basket, futsal, tennis, atau voli. Pet club dirancang agar penghuni yang memiliki hewan peliharaan juga dapat bermain dengan hewannya di taman, juga tersedia perawatan untuk hewan peliharaannya. Supermarket dirancang untuk memenuhi kebutuhan dasar penghuni, agar tidak perlu pergi keluar kawasan untuk berbelanja.

Ada beberapa hal yang dapat dihasilkan dari pembahasan di atas. Untuk membangun sebuah bangunan apung, maka perlu menggunakan pelampung yang menyerupai lambung kapal, agar bangunan bisa mengapung secara bebas di atas air. Meskipun bangunan dapat mengapung bebas, perlu dikaitkan dengan menggunakan tambat, agar bangunan tidak terbawa arus air laut. Sistem utilitas pada kawasan bisa dibuat mandiri, artinya tidak perlu bergantung pada utilitas kota. Bangunan yang dihasilkan juga perlu memperhatikan fungsi dan kondisi alam, sehingga dapat menciptakan desain yang tahan terhadap kondisi cuaca, dan juga fungsional terhadap penghuninya.

\section{KESIMPULAN DAN SARAN}

\section{Kesimpulan}

Kesimpulan yang dapat ditarik adalah bahwa sangat mungkin bagi seorang arsitek untuk membangun bangunan yang bisa berdamai dengan banjir, dalam artian, bisa beradaptasi dengan banjir, tanpa melawan alam, namun dengan beradaptasi bersama kondisi alam yang terus berubah. Selain itu, jika pemanasan global masih terus terjadi, dan masih belum ada penyelesaiannya, maka komunitas apung ini bisa menjadi solusi yang sangat baik, karena dapat diimplementasikan dengan mudah dan cepat. Pada satu sisi, penerapan sistem bangunan apung ini bisa menjadi solusi untuk berdamai dengan banjir, namun, pada sisi lainnya, jika pemilihan tempat tidak dilakukan dengan penelitian yang lebih lanjut, maka banyak sekali resiko yang dapat muncul, seperti jika terjadi badai, dan masih banyak lagi. 


\section{Saran}

Penelitian yang dilakukan ini masih memiliki banyak kekurangan seperti, sangat terbatasnya alternatif desain yang disediakan, sangat terbatasnya alternatif lokasi yang diteliti, juga sangat terbatasnya alternatif fasilitas yang diteiliti. Oleh karena itu masih harus terus dilakukan studi lanjutan agar desain bisa disempurnakan, sehingga bisa diimplementasikan secara nyata pada beberapa area lainnya. Desain yang dibuat juga tidak mutlak seperti demikan, oleh karena itu, dapat dihasilkan banyak alternatif bentuk dan desain yang lebih cocok dan tepat untuk diterapkan. Dengan dibuatnya penelitian ini, diharapkan dapat memicu desain dengan menerapkan sistem bangunan apung, sehingga kedepannya diharapkan banjir sudah tidak menjadi masalah bagi warga yang tinggal di sekitar laut lagi.

\section{REFERENSI}

Banyuurip, D., (2018), Fasilitas Umum Desa, diunduh 19 April 2021, https://banyuurip.desa.id/profildesa-49-Fasilitas.Umum.html

Bolin, B., \& Doos, B. R. (1989). Greenhouse effect. Amerika Serikat: Amerika Serikat.

Budi Prihatin, Rohani. (2013). Banjir Jakarta: Warisan Alam dan Upaya Pengendalian. Yogyakarta: INSISTPress

Denchak, M., (2017), Global Climate Change What You Need to Know, diunduh 23 Mei 2021, https://www.nrdc.org/stories/global-climate-change-what-you-need-know

Greenlee, L. F., Lawler, D. F., Freeman, B. D., Marrot, B., \& Moulin, P. (2009). Water Research. Belanda: Elsevier.

Hewitt, E., Oberg, A., Coronado, C., \& Andrews, C. (2019). Sustainable Cities and Society Vol. 48. Belanda: Elsevier.

Morra, W. S., (2015), Understanding Climate, diunduh 21 Juli 2021, https://www.climate.gov/news-features/understanding-climate/understanding-climatebilly-sweet-and-john-marra-explain

Picard, B., (2021), What is Global Warming, diunduh 21 Juli 2021, https://solarimpulse.com/global-warmingsolutions?utm_term=what\%20is\%20global\%20warming\&utm_campaign=Solutions\&utm_s ource=adwords\&utm_medium $=$ ppc\&hsa_acc $=1409680977 \&$ hsa_cam $=11451944566 \&$ hsa_

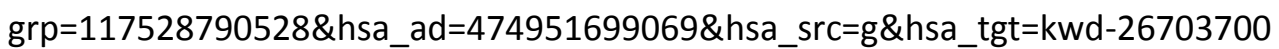

Sebestyén, G., \& Pollington, C. (2003). New Architecture and Technology. Inggris: Architectural Press.

Sutanto, A. (2020). Peta Metode Desain. Jakarta.

Turrentine, A. M., (2021), Global Warming 101, diunduh pada 23 Mei 2021, https://www.nrdc.org/stories/global-warming-101\#warming

Zaenuddin. H. M., (2013). Banjir Jakarta: Dari Zaman Jendral JP Coen (1621) Sampai Gubernur Jokowi (2013). Jakarta: Change Publicher. 